\title{
Urea and homocysteine in the blood serum of pigs fed diets supplemented with betaine and an enhanced level of B group vitamins*
}

\author{
J. Skomial', M. Gagucki and E. Sawosz \\ Warsaw Agricultural University. \\ Department of Animal Nutrition and Feed Science \\ Ciszewskiego 8, 02-786 Warsaw. Poland
}

\begin{abstract}
The aim of the study was to determine the effects of betaine and increased supplementation of vitamins $B_{6}, B_{1}$ and folic acid in pig diets on blood urea and homocysteine levels. The experiment was conducted on 64 growing-fattening pigs. The parameters under study did not differ significantly among the groups. However, in animals fed on betaine non-supplemented diets, the urea level tended to be higher, while homocysteine was lower when diets contained higher levels of B vitamins. The urea level was uniform in pigs fed diets supplemented with betaine, and homocysteine varied to a very small extent.
\end{abstract}

KEY WORDS: fatteners, betaine, vitamin $B_{6}$, vitamin $B_{12}$, folic acid, urea, homocysteine

\section{INTRODUCTION}

Methionine is an essential amino acid and is not synthesized de novo in mammalian tissues. However, when diets are deficient in methionine, its synthesis in the liver is possible from homocysteine with betaine (trimethylglycine) being the donor of methyl groups. Betaine-homocysteine methyltransferase (BHMT) or methionine synthase (in the presence of vitamin $B_{12}$ ) are involved in the process, which may be inhibited by a low level of betaine (Finkelstein et al., 1971; Remus and Virtanen, 1996). According to McDevitt et al. (2000), betaine cannot fully compensate methionine deficiency in animal diets. When there is an excess of methionine, homocysteine can be catabolised by cystathionine $\beta$-synthase to cysteine in the presence of vitamin $\mathrm{B}_{6}$. Besides vitamins $\mathrm{B}_{6}$ and $\mathrm{B}_{12 .}$. folic acid also takes part in metabolizing homocysteine to methionine (Kłosiewicz-Latoszek

\footnotetext{
- Supported by the State Committee for Scientific Research, Grant No. 5PO6E 04319

${ }^{1}$ Corresponding author: c-mail: j.skomial@ifzz.pan.pl
} 
and Ostrowska, 2000). Some data concerning the use of blood urea levels as an indicator of protein or amino acid was reported by Świątkiewicz (2003).

The aim of the study was to determine whether there are interactive effects of supplementary betaine and $B$ vitamins on the metabolism of sulphur amino acids in pigs fed diets differing in methionine content in the growing period and with the same methionine content in the finishing phase. Blood levels of urea and homocystcine were used as indicators.

\section{MATERIAL AND METHODS}

The experiment was carried out on 64 fatteners (crossbreds of Polish Landrace $\times$ Polish Large White $\times$ Duroc $\times$ Hampshire) divided into 8 groups of 4 barrows and 4 gilts. The diets fed during the growing and finishing periods contained barley, wheat, soyabcan oilmeal, soyax (full fat soyabean), Rovimix (a vitaminmineral supplement), common salt and dicalcium phosphate. The variable components were betaine ( 0 or $1.25 \mathrm{~g} / \mathrm{kg}$ ), vitamins $\mathrm{B}$ (folic acid, $\mathrm{B}_{6}$ and $\mathrm{B}_{12}$ ), and DL-methionine in the growing period (Table 1).

TABLE 1

Experimental design

\begin{tabular}{|c|c|c|c|c|c|c|c|}
\hline \multicolumn{8}{|c|}{ Groups } \\
\hline $\mathrm{I}$ & II & III & IV & $\mathrm{V}$ & $\mathrm{Vl}$ & VII & VIII \\
\hline \multicolumn{4}{|c|}{ Betaine - } & \multicolumn{4}{|c|}{ Betaine I } \\
\hline \multicolumn{2}{|c|}{ - } & \multicolumn{2}{|c|}{ Methionine } & \multicolumn{2}{|c|}{ - } & \multicolumn{2}{|c|}{ Methionine } \\
\hline LB & $\mathrm{HB}$ & LB & $H B$ & LB & $\mathrm{JIB}$ & $L B$ & IIIB \\
\hline
\end{tabular}

LB - vitamin content in $1 \mathrm{~kg}$ of mixture: folic acid $-0.25 \mathrm{mg} . \mathrm{B}_{6}-2 \mathrm{mg}, \mathrm{B}_{12}-20 \mu \mathrm{g}$

$\mathrm{HB}$ - vitamin content in $1 \mathrm{~kg}$ of mixture: folic acid $-0.50 \mathrm{mg}, \mathrm{B}_{6}-4 \mathrm{mg}, \mathrm{B}_{1},-40 \mathrm{\mu g}$

The diets fed during the growing period (up to $75 \mathrm{~kg}$ body weight) had an energy value of $13.05 \mathrm{MJ} \mathrm{ME}$, contained $164 \mathrm{~g}$ protein and $10.5 \mathrm{~g}$ lysine (per $\mathrm{kg}$ ), while the proportion of methionine + cystine to lysine was 57 (group I, II, V and VI) or 64 (groups III, IV, VII and VIII). The respective values for diets fed in the finishing period (up to $105 \mathrm{~kg}$ body weight) were $12.95 \mathrm{MJ} \mathrm{ME}, 140 \mathrm{~g}$ protein, $8.30 \mathrm{~g}$ lysine, and 63 methionine + cystine as related to lysine. Threonine and tryptophan levels in relation to lysine were 64 and 21, respectively, in both periods. The animals were fed individually according to Polish standards (1993). The diets were given in dry form, water was supplied ad libitum.

$\Lambda$ t slaughter, blood samples were taken from all pigs and urea was determined in blood serum using Vitros equipment; homocysteine was analysed by HPLC as described by Ubbink et al. (1991). The results were subjected to one-way analysis of variance using the SPSS 10.1 program. 


\section{RESULTS AND DISCUSSION}

The parameters under study did not differ significantly among the groups (Table 2). However, within the groups not supplemented with betaine, a tendency was observed towards higher urea and lower homocysteine levels in animals fed diets with higher contents of vitamins B (group II vs I and IV vs III). In the betaine-supplemented groups, the urea concentration was very uniform and

TABLE 2

Urea and homocysteine content in blood serum

\begin{tabular}{|c|c|c|c|c|c|c|c|c|}
\hline \multirow{3}{*}{ Item } & \multicolumn{8}{|c|}{ Groups } \\
\hline & I & II & III & IV & $\mathrm{V}$ & VI & VII & VIII \\
\hline & \multicolumn{4}{|c|}{ Betaine - } & \multicolumn{4}{|c|}{ Betaine +} \\
\hline Urea $\mathrm{mg} / \mathrm{dl}$ & 16.70 & 17.30 & 16.60 & 18.65 & 17.65 & 17.45 & 17.05 & 17.05 \\
\hline Homocysteine, $\mu \mathrm{mol} / \mathrm{dl}$ & 16.95 & 15.31 & 16.74 & 15.00 & 14.82 & 15.46 & 16.22 & 15.65 \\
\hline
\end{tabular}

the homocysteine concentration also varied to only a small extent. Higher supplementation of vitamins B may promote the metabolism of homocysteine to methionine or to cysteine. Both pathways can decrease the homocysteine level in blood serum while the non-utilized pool of amino acids may increase the urea content in blood. Betaine added to a diet with a high level of vitamin $\mathrm{B}_{12}$ or folic acid becomes a more efficient methyl group donor, and due to this, methionine can be better utilized for protein synthesis. Saunderson and MacKinlay (1990) pointed out that a lower methionine content in the diet can cause an increase in BHMT and stimulate remethylation of homocysteine. The opposite opinion was presented by Emmert et al. (1998), who pointed out that deficiency in methionine does not cause increased activity of BHMT, however, betaine supplementation increased its activity in the liver. The results of these two studies were not, however, univocal.

It seems that the methionine level in the experimental diet met the requirement for this amino acid and supplementation with betaine and vitamins B did not markedly influence the examined parameters in blood.

\section{CONCLUSIONS}

An increased level of $\mathrm{B}$ vitamins can influence the metabolism of sulphur amino acids and decrease the homocysteine level in blood serum. Urea and homocysteine levels, as parameters related to sulphur amino acid metabolism, seem to depend on vitamins B levels and betaine supplementation. 


\section{REFERENCES}

Emmert J.L., Webel D.M., Bichl R.R., Griffiths M.A., Garrow L.S., Garrow T.A., Baker D.H., 1998. Hepatic and renal betainc-homocysteine methyltransferase activity in pigs as affected by dictary intakes of sulfur amino acids, choline and betaine. J. Anim. Sci. 76, 606-610

Finkelstein J.J)., Kyle W.E., Harris B.I., 1971. Methionine metabolism in mammals. Regulation of homocysteine methyltranslerases in rat tissue. Arch. Biochem. Biophys. 146, 84-92

Klosiewicz-Latoszek L., Ostrowska $\Lambda ., 2000$. Diet. homocysteine and heart-vascular diseases (in Polish). Bromat. (hem. Toksykol. XXXIII (4), 381-387

McDevitt R.M., Mack S., Wallis I.R., 2000. Can betaine partially replace or enhance the effect of methionine by improving broiler growth and carcass characteristics? Brit. Poultry Sci. 41, 473480

Nutricnt Requirements of Pig. Nutritive Value of Feedstufts (in Polish), 1993. The Kielanowski Institute of Animal Physiology and Nutrition (Editor). Jabłonna (Poland)

Remus J.C., Virtanen $\mathrm{E}, 1996$. Use of liquid betaine in low methionine diets for broilers. Conference Matcrials: PSA 85-th Annual Mecting. 75, Suppl. 1, 149

Saunderson C.L., Mac Kinlay J., 1990. Changes in body-weight, composition and hepatic enzyme activities in response to dielary methionine, betaine and choline levels in growing chicks. Brit. J. Nutr, 63, 339-343

Swialkiewicz M., 2003. The level of urea nitrogen in the blood as the indicator of lysine requirement in pigs (in Polish). Post. Nauk rol. 50 (4), 37-47

Ubbink J.B., Vermaak V.I.H., Bisshort S.. 1991. Rapid high-periormance liquid chromatographic assay for total homocysteine levels in human serum. J. Chromatogr. 565, 441

\section{STRESLC'ZENIE}

\section{Zawartość mocznika i homocysteiny w krwi świń żywionych dietą z dodatkiem betainy i zwiększonym poziomem witamin $\mathrm{z}$ grupy $B$}

Celem badań przeprowadzonych na 64 tučmikach, podzielonych na 8 grup, było okresilenie wpływu dodatku betainy $\mathrm{i}$ <wiçkszonego poziomu kwasu foliowego, witaminy $B_{6} \mathrm{i}_{B_{12}}$ do micszanek na zawartośc mocznika i homocysteiny w surowicy krwi. U świn otrzymujących micszanki zawicrające mniejszą ilość witamin $z$ grupy $B$ zawartość mocznika w surowicy krwi była niższa, a homocysteiny wy/sza, gdy nic stosowano dodatku betainy. Dodatek betainy nieznacznie zmniejszal zawartość homocysteiny, a nie miał wpływu na poziom mocznika. Róznice te nie były istotne statystycznic. Odnotowano odwrotna zależnośc między zawartością homocystciny i mocznika w surowicy krwi. 